IDEAS in AGORA 

DOI: $10.1515 /$ hssr -2015-0002

\title{
The Intertheoricity: Plasticity, Elasticity and Hybridity of Theories
}

Astrid Guillaume*

Paris IV Sorbonne University, France

\begin{abstract}
Theories are processes modelled by thought. When they evolve in time, they are transformed and become new theories. They may cross from one academic discipline to another, then open up to new areas of human knowledge, mixing together the humanities, art, science and even spirituality. The way they are modelled reveals their plasticity and their elasticity is tested in their potential for transfer from one domain to another, while the different contacts they make and mergers they undergo generate a certain hybridity. Plasticity, elasticity and hybridity are the triad which make the transfer of theories possible.
\end{abstract}

Keywords

Intertheoricity, Plasticiy, Hybridity, Linguistics, Transdisciplinarity.

«Rien ne se perd, rien ne se crée, tout se transforme "

Nothing is lost, nothing is created, everything is transformed)

Antoine Laurent de Lavoisier

Theories are processes of abstract thinking, often schematic and schematized; they are studied synchronically as well as diachronically. Certain theories are cumulative (theory of numbers), others are evolutive,

\footnotetext{
* EA4509 Sens, Texte, Informatique, Histoire, Paris-Sorbonne University, 1, Victor Cousin Str., 75005 Paris, France; astrid.guillaume@live.fr (Article translated into English by Sorina Chiper, University Alexandru Ioan Cuza Iasi).
} 
transferable and adaptable (F. Rastier), others evolve by virtue of their creator, but not by external osmosis (A. J. Greimas). The three forms of theories are complementary, and this diversity counts as richness for research. When theories are mono-disciplinary, they evolve little; when they evolve, this is because they can open up to or be applied to other areas of knowledge that will take hold of them so as to transform them. They thus become new theories, bearing in themselves some traces (a modified schema here, a term there) of other theories that are very old or still very topical. Intertextuality, intermediality and interartiality are increasingly more talked about; intertheoricity, on the other hand, is very rarely evoked and practiced in human and social sciences (henceforth HSS), yet it opens the way to a new manner of understanding yesterday's theories and of creating those of tomorrow. Transferogenesis, the theorisation of a cultural object's transfer process, is an example of intertheoricity and elasticity of theories.

Elasticity is a term frequently used in economics to explain variations of a certain size. The notion of variation in relation to a source theory is the contact point that will allow one part of a theory to migrate, hence its elasticity on one (or several) contact point(s), its new plasticity and final bybridity. If words and expressions evolve in time and are transformed in contact with words from other languages/cultures/contexts, theories in HSS have mutated little over the past century; therefore we can state that they have not proved to be very elastic. Elasticity defines here a (disciplinary, but also spatial and temporal) extension which implies, specifically, a transformation of certain aspects of a theory. Certain theories are fixed and they seem deprived of this elasticity. It is true that in certain cases, theory has something of a registered trademark, of a quasi-brevet, and as such its elasticity is hardly negotiable. Whoever would attempt, jokingly, or would take the risk, in fact, to switch, even mix, the terminology of two different, even opposed, schools of thinking, would take a certain risk, that of upsetting both currents. However in sciences, diachronically, and in arts, synchronically, it is in crossing theories and approaches that evolutions occur in contact with advances of contemporary thinkers or of thinkers from previous centuries.

From among the HSS, we shall take linguistics as an example. Rarely 
do theories enter a circle of transformation or re-composition. They have a very slow and mostly autonomous evolution process. HSS researchers, who work less frequently in a team than researchers in biology or in medicine, create their theories, which explains why the latter undergo few transformations. For a long time, they were only constructed in mono-disciplinary fields, and it is only for the past one or two decades that they have opened themselves to pluridisciplinarity, interdisciplinarity or transdisciplinarity; the recontextualisation, indispensable to these approaches, opens new scientific horizons.

Despite this absence of interdisciplinary telescoping, theories of certain theorists have experienced a beautiful post-mortem life: this is the case of Ferdinand de Saussure's theories, and to a lesser extent those of Peirce, which are more complex and abstract, or those of Greimas that are applied in France even at the level of secondary education - a quite rare fact to be highlighted. Nowadays, it is François Rastier's theories that open new fields of knowledge and prove, in so doing, that they have a plastic, elastic and bybrid character, in the sense that they can be transferred and made to evolve somewhere else and differently ${ }^{1}$, but also because these are theories that, while generating hybridity, carry in themselves this opening towards hybridity, whose origin is elasticity and plasticity, at the heart of intertheoricity.

\section{Intertheoricity}

In transdisciplinarity, theories are intertwining; they thus open up disciplines as well as fields of human knowledge, placing humanities side by side with sciences, as well as the arts and spiritualities of the world, the latter having not always been considered autonomous university disciplines. They have been acknowledged as "sciences" by universities since quite recently (sciences of art, religious sciences), where science is understood as a production of the human spirit, to be studied historically. Religious sciences do not grant any scientific status to spiritualities, however they allow the analysis of their contextual process in time. In this respect, it is useful to integrate them in analyses of societies, to which they undeniably belong; the same holds true for the "sciences" of art. Art does not acquire any scientific status but its history is part of human thought, which it has influenced in multiple ways. The 
influence of arts and spiritualities on cultures is major, as well as on the creation of theories, which is carried out at different levels:

- a first, pre-disciplinary level, will prioritise the intuitive over the scientific; such a literary or sacred reading will favour a certain intuition or a certain scientific or artistic work (Kandinsky);

- a second level privileges only scientific facts, or gives them priority over intuitive facts, and it will study the history of the discipline, or certain elements in time depending on different contexts (Einstein);

- a third level mixes the previous two in alternation (Merleau-Ponty, Bergson, Peirce).

However, as an autonomous field of human knowledge, arts (and their techniques) and spiritualities influence human thinking, sometimes in adhesion, other times in radical opposition but in this respect, they inter-react implicitly or explicitly in the theorisation of human and social sciences. These intra-disciplinary contacts that connect arts, sciences, religions and humanities, briefly, the buman context, open up towards different approaches that allow one to study more precisely the sciences of culture, as they are described in François Rastier's works ${ }^{2}$ in connection with a linguistic anthropology and an anthropological linguistics.

\section{Theories: an often geometric plasticity}

Theories are often accompanied by a very precise process and a targeted terminology to be applied almost letter by letter and figure by figure. Depending on disciplines, formulas from mathematics and physics are associated to them, with schemata that model or summarise the process to be demonstrated in a figure that is often geometrical. There are no theories without a model. In linguistics, models summarise, visually, a narrative or discursive theory, or a phenomenon that is developing in time, thus contributing a further visual and spatial reference. This geometric modelling contributes to lending theories their scientific character and it thus brings their plasticity.

Geometry, the consecrated symbol of precision par excellence, reflects, somehow, what can be found at microscopic and macroscopic level, from the visible and the invisible, or from the infinitely little and the infinitely grand. All depends on and is connected to geometry and its 
forms (circles, semi-circles, curves, triangles, rectangles, points, lines, plans, depth, spaces, axes, levels and dynamics).

At a spiritual level, Egyptian pyramids, colossal tombs that allow whoever rests in them to enter after-life, remain geometrical jewels; the Jewish and Arabian cultures are attached to gematria; medieval Christian cathedrals are caskets of highly precise calculus, strategic orientations in relation to space and light, of rosettes and geometric stained glass; the Muslim religion has conferred geometry an artistic status that permits to confirm the presence of the divine. Similarly, Buddhists and Hindus, via cosmogonical mandalas, also privilege geometry. Associations of figures and letters, architectural buildings or signs, and art works symbolise, in the spiritual context, the indisputable proof of a Creator and the perfection of His creations and creatures.

One can encounter geometry again in theoretical modellings and schematic thinking, but also at the heart of matter when it is looked at from a much closer distance with an electronic scanning microscope or through Electron BackScatter Diffraction (EBSD).

In sciences, atoms, matter, the DNA, chromosomes and space have always been represented by lines, axes or curves that unite points, granting any thing its own identity, a signature which distinguishes each living being, non-transferable digital imprints to create the uniqueness of all matter, of all theorem, of all living being, ad infinitum: a plurality of unicities that leads to the diversity of unities, mutually ad infinitum. This geometrical representation pertains to the scientific imaginary, which privileges it in vulgarisation. Arcy Thompson's thoughts on forms shed an interesting light on the "elasticity of geometry" or the coincidences that allow one to find it in various areas of knowledge ${ }^{3}$. Currently, for instance, CNRS studies the phenomenon of cyclones with the help of the evolution of soap bubbles subjected to different phenomena of instabilities, thus recreating at a much smaller scale the turbulences of the cyclone. This passage from the situation of the infinitely grand towards a more accessible scale that is nevertheless comparable at the level of reactions, is an example of a transfer that can be studied via transferogenesis. A form of abstract art that is present, at a microscopic sc//ale, symbolically at the heart of any of us and of everything that surrounds us, and at a macroscopic scale at planet level. As if all these 
abstract artists had been aware of this invisible geometry even before science could demonstrate $\mathrm{it}^{4}$. By changing an atom, modifying the curve of a line or the place of a point of a micrometre, by permuting a figure or moving a comma, everything becomes different and even ceases to exist and life, all of a sudden, disappears from the planet.

In art, from the time of ancient Egypt up to Kandinsky's time or more recently in intermedial choreographies such as the ones created by the Japanese group Enra, geometry has entered contemporary choreographic art; it has proved its worth in matters of orientation, of conceptions and innovative creations, of perspective and depth of field, of symbolism, of colours of abstraction. Intermediality allows the crossing of these spheres of application by multiplying the realms of the possible. Bridget Riley develops an implicit and explicit dynamics that brings together games of contrasts, perspective and geometry, a process that is specific to the kinetic art. Auguste Herbin, an engaged artist that practices abstract art, creates a "plastic alphabet", thus associating letters, forms, colours and musical notes. In Danseuse (1942), he develops the following alphabet: D (clear red circle, do, re), A (rose, a combination of circular, triangular, semi-circular and square forms, do, re, mi, fa, sol, la, si), N (white, a combination of all forms and notes as A), S (intense bluegreen, a combination of semi-circular and triangular forms, la, sol, fa), E (red, circle, do), U (blue, semi-circle, sol, la). What the artiste seeks here is to recreate a composition that privileges dynamics and moves close to choreographic dance, dense colours whose geometric rigour oscillates between science and aesthetics, taking art fully towards the path of the Sciences of art. But it is not only abstract art that owns the interpretative exclusiveness of decoding because Dürer and Cranach were already playing with the symbolism of the signs and space to be interpreted in their respective Melancholia paintings, in which geometry does not become more visible but invisible and implicit; it organises the painting and holds its meaning. The same is true for heraldry, ${ }^{5}$ which emerged and developed in the Middle Age.

We have proved somewhere else that medieval artists had worked on drawing a code of colours and space $^{6}$ in representations of the Last Judgment, which in the early $20^{\text {th }}$ century are always identical on the spatial plane of the Middle Age. This approach, which becomes an 
implicit language, proper to artists who work on Last Judgements, allows one not only to go beyond the common or conventional artistic language but also to discover genuine parallel languages, whose alphabets are colours, codes and visible or invisible signs, that allow messages to be conveyed just like in any other language. These artistic languages permit, especially, the opening towards the unknown and all other forms of languages which are not understood from the first and require efforts to be fully grasped, as the animal language that is highly studied now.

Similarly in theatre, increasingly more productions bring together on stage movement, dynamics, meaning and text. Yves Marc, co-director of Theatre of movement, describes it as lying "on the borders of a dramatic dance, a theatre of object, a textual theatre in which the body is engaged", thus setting in relation the possible dialogues of text and movement, the body itself becoming geometry in connection with the text. Starting from this type of approaches, it is easy to conceive of arts as being able to overcome the stage of simple emotion conveyed or perceived, as being analysable scientifically just like sciences, so as not to send back solely to the aesthetic and emotional sphere.

In human sciences, geometry is present in schemata of modelling thought. It allows, schematically, to represent all theoretical processes in time and space. Pragmatic semiotics, narrative semiotics, interpretative semantics, discursive semiotics, the theory of signs, maybe more than any other discipline of the sciences of language, have produced numerous theoretical schemata. We are thinking especially of Peirce and his triads, of Greimas and the semiotic square, established in collaboration with François Rastier, of Gustave Guillaume and his binary tensions ${ }^{7}$. 
HSS, vol. IV, no. 1 (2015): 13-29

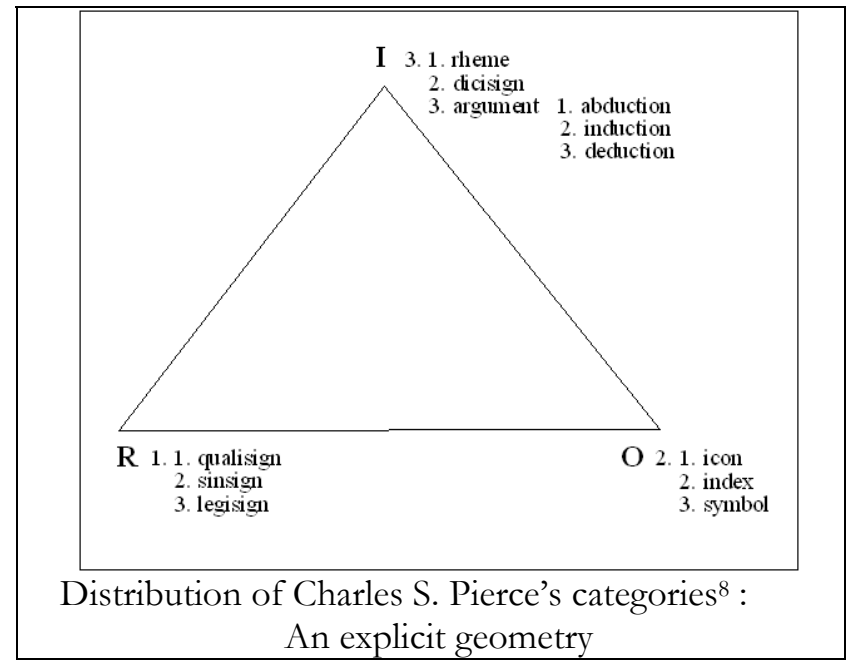

Figures 1- Basic geometric form in Pierce's semiotics

Without intending to essentialise, geometry will be, for our argument in any case, the sometimes implicit, sometimes explicit link in our modellings, to unite contexts behind the prism of theories: life sciences, physics, mathematics, arts, human sciences as well as spiritualities of the world. As a common matter, it becomes the cement that facilitates the theorisation of sciences of culture, thus offering it a form and a plasticity to be declined ad infinitum. This geometry, mainly Euclidian in a first stage (symmetrical, centred figure), becomes non-Euclidian when the theory is deformed under the process of elasticity ( $C f$. for a mathematical topology, Möbius' ribbon).

Medieval artists and cathedral builders, mostly anonymous, knew how to give a voice, a meaning and forms to colours, with ingenious architectural procedures that have not been matched ever since; $20^{\text {th }}$ century abstract artists like Kandinsky, Herbin or Delaunay made the emotion of the invisible vibrate, by offering it alphabets of forms and colours; scientists, through the progress of technology, have managed to prove and to show the invisible microscopic and macroscopic realm, and architects who drew their inspiration from art have overcome technological limits by working on the resistance of materials. Now it is high time for human sciences to enter the invisible areas of abstract 
Astrid Guillaume, The Intertheoricity: Plasticity, Elasticity and Hybridity of Theories

HSS, vol. IV, no. 1 (2015): 13-29

theoretical creation for more innovations and creativity in the Humanities, and maybe their various fields of reflection and competence will also receive more recognition, thus fully opening the path to studies on the sciences of culture?

\section{Theorists, theories, disciples}

In the image of everything that can be found on earth, theories are also the reflection of that which cannot be modified or become something else. If theories do not undergo mutations in the biological meaning of the term, at least they undergo transformations. An even minimal change in a theory or a genome unavoidably leads to a new theory, to a new matter, a new creature, a new figure and so a new creation. This is equally true in the case of a vaccine, a text, a painting, or any literary and artistic work. Evolution in nature is Darwinian or Lamarckian, but no matter how it could be, it is noticed diachronically, $a$ posteriori. Nowadays, via the genome, one influences the mutations of certain creatures (vegetal and animal creatures for the moment). But unlike in the case of matter, of the genome or of the DNA, theories are quite often associated with a researcher who is, somehow, their Creator, the father or grand geometer, if we were to pursue the divine or sacred metaphor. Theories are registered marks, controlled appellations; they belong, in the proper and figurative meaning of the word, to a person, who has been called, since ancient times, a master - a scholastic term, we could say, because who says master, says pupils or disciples. With his theories, the master will found a school, even a School of thinking which will bring a certain thought to a School, in which disciples will apply his theories, his ideology and ethics, until the disciples themselves create their own theories in harmony with those of the master or, on the contrary, in open opposition - the quite frequent sign of a final rupture between persons.

Since Kant, philosophy has been functioning according to the model of adherence or rejection of predecessors because, in the image of sacrality, theories in HSS are quite immutable; in certain cases, they prove to be like relics, which are more convenient to venerate for fear of altering them outside of the clues of the Father who has thought them, a quasi-mystical approach even among the most atheist among 
philosophers. Strict rules to be known and applied for obvious reasons even if they have never been formally fixed, in HSS in any case, but they implicitly draw their models on those of sciences and as such, they acquire this quasi divine character for some, and immutable for others. Nevertheless, to apply a theory - and certain researchers dedicate their life to applying the theories of only one theorist from the previous century -, one needs to know precisely the grounds and results, the history, the glossary or the terminology in the case of HSS, and formulas, theorems and equations in the case of mathematics, physics and chemistry. This is actually the minimum to master so that a theory could be applied and function according to the model which defines it.

If nature evolves in time, if animals and plants are in perpetual mutations depending on their life contexts, by adjusting themselves to their environment which does not cease to change (Lamarckian evolution), similarly theories in sciences as well as in arts have been progressing and multiplying at high speed for centuries. With them, as consequences, innovation in technology, medicine, biology, astrophysics, digital sciences and creativity in arts, rival in new discoveries through their intercultural, intertemporal and - since recently - intermedial hybridity.

In HSS, theories and theorists are much fewer than in other fields of knowledge; the contexts in which these rare theories are applied (language, literature, philosophy, society, psychology) do not allow for check-ups that are as surgical as in medical sciences, or for applications as free and liberated as in the arts. This reality tends to let one think that theories in HSS are neither elastic nor hybrid, even though they have a plasticity of their own. Undeniably, this absence represents an obstacle to the new, by preventing more spontaneous, intuitive theoretical, even aesthetic productions, anchored in the realm of what is felt or in the affect, which would allow students to create their own theories. The opening of workshops in theorising, for instance, would be some interesting progress.

Grégory Chatonsky, in an article titled "Multiplicities", writes the following in relation to the diversity of theories in the artistic field:

"No theoretically unified approach is interesting unless it is associated with other approaches because this setting in relation is analogous to the 
capacity of technological connection and disconnection: (...) it would be wrong to become attached to a single corpus which becomes ideology, and which as such is reassuring (one knows what to hold on to) yet restrictive and simplifying"10.

We would add that the approach to sacralise theories or to follow just one of them is an equally restrictive attitude which is no longer in harmony with the actual world that has become multicultural, hybrid, multiethnic, multimedial and in continuous transformation, where everybody is expected to have a potential for adaptability and flexibility as never before in the history of humanity. Many theories remain static, as if from another age, from which they undeniably come, as when the Antiquity and its philosophers are systematically called upon to analyse one of the most contemporary situations: if the approach could seem scholarly, the transferability of arguments is quite often risked because it is impossible. An idea, summarised in a phrase, is transferred but not the entirety of the arguments of the ancient author; what credit could one lend to this unique idea, further decontextualised from its original age?

The plurality of cultures and the contact between cultures in our multicultural societies has enabled many innovations in contemporary art. These innovations are sometimes worrying for novices - a romantic landscape that represents a mountain is much more reassuring than a contemporary work which cannot be understood from the first glance and which requires an interaction with the observer to have access to a part of its often interartial aesthetics -, but they are faithful to the contemporary, hybrid, complex, changing, innovating, dynamic, crossbred world. The respect for the diversity of modes of thinking undergoes an even greater hybridity in the theorizing processes of these modes of thinking. A multiplicity of approaches, a diversity of models, a crossbreed of modellings, a hybridity of theories overcoming conflicts of persons should also be able to cohabit with the forms of monodisciplinary or individualising thinking, getting out of the Manichaeism of for or against, becoming theoretical, quasi artistic creations so as to dis-antagonise the Schools of thinking and the conflicts that are too often associated to them, but also and especially to open up areas of research. 
Astrid Guillaume, The Intertheoricity: Plasticity, Elasticity and Hybridity of Theories

HSS, vol. IV, no. 1 (2015): 13-29

\section{Plasticity, elasticity and bybridity of theories}

The plasticity of theories is directly connected to their modelling or schematisation. Theories are plastic when they are modelled. This plasticity, which characterises them, allows the immediate recognition of X's or Y's theory. The terminology that accompanies models is the mark of the age which saw them emerge, the lexical and aesthetic touch that is characteristic for their century, the personal touch of their author. Via intertheoricity, modellings and terminologies can mix together and create a new plasticity accompanied by hybrid terms. Theories are plastic also because their modelling lends them a form, which becomes matter in dynamics. Synchronically, they evolve spatially; diachronically, they evolve temporally.

- Elasticity is more difficult to achieve: with rare exceptions, theories in HSS and especially in linguistics are the opposite of what we could term elastic. They neither extend nor deform themselves ad infinitum. They cannot always be modelled. However, they are plastic, as their modelling lends them a certain plastic schematic representation, which can even be aesthetic when the modelling draws directly on the schema of thinking of an artist or nowadays, of microscope images, for instance. Theories can evolve in sciences: electricity, electronics, computer science and digital sciences are one succession of theories and discoveries across several centuries, and the entire phenomenon, diachronically, features a certain elasticity. Synchronically, on the other hand, this is not the case. They show their elasticity only when they pass from one sphere of knowledge to another but rarely within the same discipline. Similarly in art, the plastic theories and techniques of Impressionists nourished Expressionists, who, themselves, influenced abstract painters, who could, in their turn, influence philosophers, architects and musicians, up to contemporary designers and couturiers. When advances made in one theory enter another field of knowledge, the elasticity of this theory or of the product of the theory is demonstrated, which becomes a hybrid, i.e. a mix of several disciplinary fields.

- this bybridity at the criss-cross of fields of creation leads to new thoughts and forms, a symbol of our age. Inquiry on hybridity is, actually, very topical within increasingly hybrid societies through their multiculturality and their cross-breeding, where identities are no longer 
made out of a single culture but out of several. This was not the case a century ago and even less so during the preceding centuries. These diversities are a richness that contributes considerably to creativity.

At the artistic level, Roy Lichtenstein's works represent a good illustration of this process of hybridity, which integrates the philosophy, the techniques and the theories of several other artists from different cultures, to create an entirely unique work. With reference to his art, Roy Lichtenstein argued that "I do not think that I make parodies. I think I reinterpret previous works in my own style, like Picasso when he reinvents Velasquea, Delacroix or Rembrandt ${ }^{* 11}$. The result is equally innovative and interesting; in fact, Roy Lichtenstein's exhibition in Centre Pompidou in Paris has been one of the most successful since the foundation of the Centre. The two other artists who also broke visitor records are two painters who worked on the hybridity of theories, of matter or techniques, Kandinsky and Soulages: Kandinsky, through his static forms that are nevertheless in movement in a space of pre-established definitions; Soulages, through his work on the matter in direct connection with light, which makes white spring off from black, and black from white, thus showing the elasticity of both white and black and their own limit. Bill Viola is also a telling example in terms of intermediality when, influenced by a Zen Japanese spirituality, he mixes video, electronic music or deaf sounds to explore the space-time and the characteristic features of the human condition. In art, it is the hybridity of approaches and theories in contact with other artists, other sensibilities and other spiritualities that has undeniably created innovation and generated creativity.

This intellectual approach is difficult in linguistics, yet it is possible in the semiotics of cultures; it is precisely this elasticity that enables sciences of culture to analyse and understand various fields of culture. Quite often, conferences on semiotics bring together extremely varied types of research. The hybridity acquired when being in contact with other civilisations, other disciplinary fields or other theories are the soul of a culture; it is also that which makes theories elastic. This elasticity allows them to become hybrid in the age of transformation. This leads us directly to the triad: plasticity, elasticity, hybridity, which lies at the heart of the process of intertheoricity: 


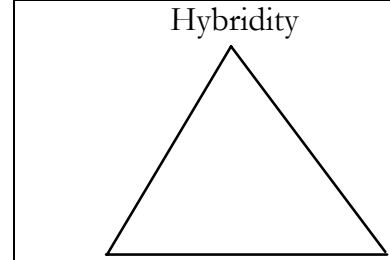

Plasticity Elasticity

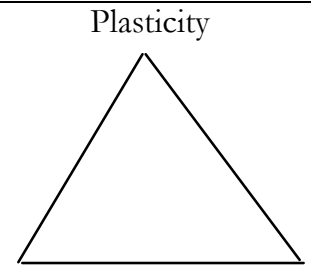

Elasticity

Hybridity

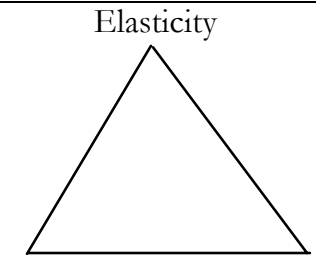

Hybridity

Plasticity

Figure $2:$ Internal geometry of intertheoricity

The Internal geometry symbolises three distinctive moments in a transfer process, in this case the intertheoricity process: it prioritises one of the concepts at the top of the triangle, at the moment of transfer towards another genre, another work or another creation. Sometimes hybridity will prevail, other times elasticity and other times plasticity, hence three triangles which feature an alternation depending on the moment at the heart of the process of transformation. The triangle is here privileged - a geometric figure that Peirce was fond of and that is very much present in the history of art. On a theoretical level, the triangle enables a dynamics of tension and avoids binarism via too much Manichaeism, a binarism to which we shall return in the context of the ethics to which it adjusts easily. The process of intertheoricity in action and in movement is modelled via a tri-triangular dynamics, schematised as follows:

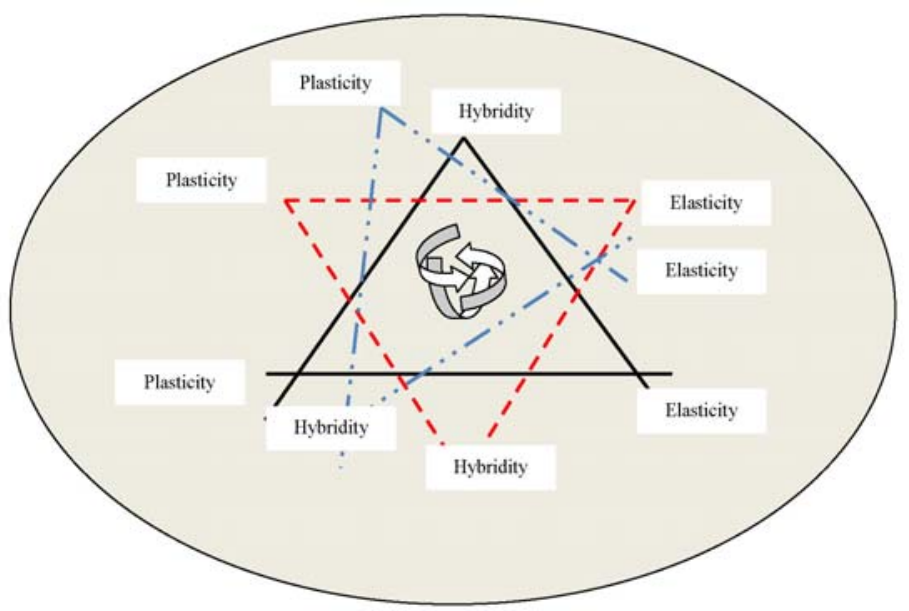

Figure 3: Tri-triangular dynamics of intertheoricity 
The tri-triangular dynamics of intertheoricity presents the process in action with its dynamics. In order for the transfer of a theory to another to be operated, the three processes must be able to co-exist permanently, which opens up a dynamics of composition/decomposition/recomposition setting plasticity in connection with the modelling of the first theory, elasticity in connection with the transfer of context (diachronically and/or synchronically) towards a new theory, bybridity in connection with the plasticity of the new theory, acquired via transfer.

This development in the interest of intertheoricity leads us directly to the notion of transferogenesis, which represents the internal process that is set into place in the transfer of cultural objects, by fusing different elements from several theories. It feeds on the thoughts and theories of C.S. Peirce (triad, (tri-)triangularity), F. de Saussure (diachrony-synchrony, folk etymology, diachronic linguistics, diversity of languages), G. Guillaume (binary tension and genesis of a theoretical process: in posse, in fieri, in esse), F. Rastier (semiotics of cultures, cultural object /waste, praxeological typology) in order to define the tensions and harmonic relation that are at work in a transfer process, as well as the necessary conditions for them to occur. (To be continued)

\section{References}

Ablali, Driss, Badir, Sémir, Ducard, Dominique (ed.), Textes, Documents, OEurre : Perspectives sémiotiques, Presses universitaires de Rennes, 2014.

Blanchaud, Pierre, «Le signifié de puissance du futur hypothétique », 2013, Cadix,

Xe Congrès international de linguistique française,. http://www.gustave guillaume.org/images/PDF/EXPOSE_POUR_CADIX.pdf

Guillaume, Astrid, "L'Épreuve de Dieu : les preuves de Dieu. Le non-dit in puissance dans le Tristan de Béroul », Mélanges de Science Religieuse, no 3 JulySeptember 2008, 65, 7-30.

Guillaume, Astrid, «"Medieval" Time(s) : Last Judgements », Semiotics 2009 - The Semiotics of Time, edited by Karen Haworth, Jason Hogue, Leonard G. Sbrocchi, Proceedings of the 34th Annual Meeting of the Semiotic Society of America, Legas publishing, 2010, 132-146.

Guillaume, Astrid, «Langues et Traductions médiévales : Que de mots ! Que de maux!», Théories et Pratiques de la terminologie : analyser des termes and des concepts, ed. Jean-Jacques Briu, Peter Lang, 16., 2011., 131-151. 
Guillaume, Astrid, « Pour une sémiotique diachronique des cultures : le "Moyen Âge" aujourd'hui », in Textes, Documents, OEuvre : Perspectives sémiotiques, ed. Driss Ablali, Sémir Badir, Dominique Ducard, Cerisy-la-Salle July 2012, Presses universitaires de Rennes, 2014, 381-406.

Guillaume, Astrid, "De la morale médiévale à l'éthique contemporaine : sémiotique de la valeur d'hier and d'aujourd'hui », in Valeurs. Aux Fondements de la sémiotique, ed. Amir Biglari, Paris: L'Harmattan, (in print).

Guillaume, Gustave, Temps et verbe. Théorie des aspects, des modes and des temps followed by L'architectonique du temps dans les langues classiques, Paris, Honoré Champion, 1984.

Kandinsky, Vassily, Du spiritual dans l'art, and dans la peinture en particulier, DenoëlGonthier, 1969, 1979, 1989 ; Gallimard, coll. «Folio Essais », 1989.

Lévi-Strauss, Claude, Anthropologie Structurale T.2, Paris, Pocket, 2003.

Lévi-Strauss, Claude, Anthropologie Structurale T.1, Paris, Pocket, 2003.

Medvedkova, Olga, Kandinsky, le peintre de l'invisible, Paris, Gallimard, 2009.

Merleau-Ponty, Maurice, Le Visible et l'invisible, published by Cl. Lefort, Gallimard, 1964.

Peirce, Charles Sanders, Écrits sur le signe, assembled, translated and commented by G. Deledalle, Paris, Seuil, 1978.

Rastier, François, «Objets culturels et performances sémiotiques - L'objectivation critique dans les sciences de la culture », Performances et objets Culturels, Louis Hébert and Lucie Guillemette (ed.), Québec : PU Laval, 2011, 15-58.

Rastier, François, "Anthropologie linguistique et sémiotique des cultures », F. Rastier and S. Bouquet (eds.), Une introduction aux sciences de la culture, Paris, PUF, 2002, 243-267.

Rastier, François, «L'action et le sens - pour une sémiotique des cultures », Journal des anthropologues, 85-86, May 2001, 183-219.

Saussure, Ferdinand, de, Cours de linguistique générale, Paris, Payot, 1972.

Thompson, D'Arcy Wentworth, Forme et croissance, trad. Dominique Teyssié, Paris, Seuil, 2009.

${ }^{1}$ To have an overview of the different fields of application and innovation that François Rastier's theories have engendered in the HSS, seee Textes, Documents, Euvre: Perspectives sémiotiques, ed. Driss Ablali, Sémir Badir, Dominique Ducard, Cerisy-la-Salle, July 2012, Presses universitaires de Rennes, 2014.

${ }^{2}$ Cf. François Rastier, « Anthropologie linguistique et sémiotique des cultures », F. Rastier et S. Bouquet (eds.), Une introduction aux sciences de la culture, Paris, PUF, 2002, pp. 243-267 and François Rastier, « Objets culturels et performances sémiotiques - 
Astrid Guillaume, The Intertheoricity: Plasticity, Elasticity and Hybridity of Theories

HSS, vol. IV, no. 1 (2015): 13-29

L'objectivation critique dans les sciences de la culture ", Performances et objets culturels, Louis Hébert et Lucie Guillemette (ed.), PU Laval, Québec, 2011, pp. 15-58.

${ }^{3}$ D'Arcy Wentworth Thompson, Forme et croissance, trad. Dominique Teyssié, Seuil, col. « Science ouverte », 2009.

${ }^{4}$ Cf. the abstraction of the living on Universciences, $\mathrm{n}^{\circ} 258$, « La nuit du vivant. Beauté, Vertus et Délices ", Geneviève Anhoury, Ex Nihilo, CNRS Images, in association with Universcience : http://www.universcience.tv/

${ }^{5}$ Astrid Guillaume, «Langues et Traductions médiévales: Que de mots! Que de maux!», in Théories et Pratiques de la terminologie : analyser des termes et des concepts, ed. Jean-Jacques Briu, Peter Lang, volume 16, 2011, pp. 131-151.

${ }_{6}^{6}$ Astrid Guillaume, " "Medieval" Time(s) : Last Judgments », in Semiotics 2009 - The Semiotics of Time, edited by Karen Haworth, Jason Hogue, Leonard G. Sbrocchi, Proceedings of the $34^{\text {th }}$ Annual Meeting of the Semiotic Society of America, Legas publishing, 2010, pp. 132-146.

7 Pierre Blanchaud, «Le signifié de puissance du futur hypothétique », 2013, Cadix, $\mathrm{X}^{\mathrm{e}}$ Congrès international de linguistique française, in http://www.gustaveguillaume.org/images/PDF/EXPOSE_POUR_CADIX.pdf

${ }^{8}$ «Peirce's Semiotics», Nicole Everaert-Desmedt http://www.signosemio.com/ peirce/semiotics.asp

${ }^{9}$ Cf. François Rastier and Simon Bouquet (eds.), Une introduction aux sciences de la culture, PUF, 2002.

10 Grégory Chatonsky, «Multiplicités », available online, Fragment, 2006. http://chatonsky.net/fragments/multiplicites/

11 Exposition Roy Lichtenstein, Centre Pompidou, 2013: http://www. dailymotion.com/video/x12bh6j_bull-profile-series-1973-de-roy-lichtensteinexposition-roy-lichtenstein-du-3-juillet-2013-au-4-nov_creation

\section{Biographical note}

Astrid Guillaume, HDR, is an assistant professor at the Paris Sorbonne University (Paris IV), Director of the collection Traditions et Croyances aux Presses de l'Université Paris-Sorbonne, member of the International Center for Transdisciplinary Research (CIRET), member of the scientific committee of the Fondation Droit Animal, Ethique et Sciences (LFDA) and founder vice-president of the European Observatory on Plurilinguism (EOP). She authored mainly Plurilinguisme, Interculturalité et Emploi : Défis pour l'Europe, L'Harmattan, 2009; " Pour une sémiotique diachronique des cultures : le "Moyen-Âge" aujourd'hui », in Textes, Documents, OEuvre : Perspectives sémiotiques (Autour de Francois Rastier), Presses universitaires de Rennes, 2012. 